\title{
Pemerolehan Honorifik Bahasa Korea oleh Pemelajar Indonesia
}

\author{
Ghina Mardhiyah, Syihabuddin, Eri Kurniawan, \& Didin Samsudin \\ Program Studi Linguistik, Universitas Pendidikan Indonesia \\ ghinajina25@gmail.com; syihabuddin@upi.edu; eri.kurniawan@upi.edu; \\ didinsamsudin@upi.edu
}

How to cite (in APA Style): Mardhiyah, G., Syihabuddin, Kurniawan, E., Samsudin, D. Pemerolehan honorific Bahasa Korea oleh pemelajar Indonesia. Jurnal Pendidikan Bahasa dan Sastra, 18(2), doi: 10.17509/bs_jpbsp.v18i2.15507

Article History: Received (04 April 2018); Revised (23 August 2018); Accepted (01 October 2018).

Journal homepage: http://ejournal.upi.edu./index.php/BS_JPBSP

\begin{abstract}
Abstrak: Bahasa Korea termasuk ke dalam bahasa aglutinatif, yaitu pemakaian afiksasi untuk berbagai tujuan ekspresif, di antaranya untuk menerapkan prinsip kesantunan berbahasa. Persoalannya, apakah para pemelajar bahasa Korea memiliki kemampuan untuk menerapkan prinsip kesantunan melalui proses morfologis bagi tujuan honorifik? Untuk menjawab pertanyaan ini dikumpulkanlah data yang diperoleh dari sekelompok pemelajar bahasa Korea di kota Bandung. Mereka berjumlah 20 orang, berlatar belakang budaya Sunda, berusia antara 18-31 tahun, sebagian berprofesi sebagai penerjemah bahasa Korea, dan dikelompokkan sebagai pemelajar tingkat lanjut. Hasil tes menunjukkan nilai ratarata sebesar 70,5 dan belum mencapai skor ideal tingkat lanjut yang ditetapkan peneliti, yaitu 81-100. Menurut para ahli, standar pencapaian pemelajar tingkat lanjut terbagi dalam empat kategori, salah satunya ialah pemelajar dapat menggunakan dan menjelaskan interpretasi aspek-aspek tatabahasa, serta aspek konteks dari sintak suatu bahasa. Hasil penelitian ini belum menunjukkan adanya kemampuan pada kategori tersebut. Pemerolehan honorifik tanpa imbuhan (Kondisi 1) dan cukup didasarkan pada konteks lebih sulit diperoleh pemelajar daripada honorifik dengan imbuhan (Kondisi 4). Untuk mengatasi kesulitan tersebut dan untuk meningkatkan kemahiran, para pemelajar memanfaatkan media hiburan berbahasa Korea.
\end{abstract}

Kata kunci: honorifik; bahasa Korea; pemerolehan bahasa kedua

\section{Honorific Acquisition in Korean Language by Indonesian Students}

\begin{abstract}
Korean language is included in agglutinative language, which is the use of affixation for various expressive purposes, including to apply the politeness principle of language. The problem is, do Korean language learners have the ability to apply the principle of politeness through a morphological process for the purpose of honorifics? To answer this question data was collected from a group of Korean language learners in the city of Bandung. They are 20 people, with a Sundanese cultural background, aged between 18-31 years, some work as Korean translators, and are classified as advanced learners. The test results showed an average score of 70.5 and had not yet reached the ideal level of the score set by the researcher, which was 81-100. According to experts, the standard of achievement of advanced learners is divided into four categories, one of which is that learners can use and explain interpretations of grammatical aspects, as well as aspects of context from the syntax of a language. The results of this study have not shown any ability in that category. Earnings of honorifics without additives (Condition 1) and sufficiently based on context are more difficult for students to obtain than honorifics with additions (Condition 4). To overcome these difficulties and to improve proficiency, students use Korean-language entertainment media.
\end{abstract}

Keywords: honorifics; Korean; second language acquisition 


\section{PENDAHULUAN}

Untuk memperlancar komunikasi, pada umumnya berbagai bahasa memiliki piranti kesantunan yang berfungsi untuk menghormati mitra tutur. Di antara bahasa tersebut ialah bahasa Korea yang memiliki piranti spesifik bentuk penghormatan yang disebut honorifik. Secara singkat politeness dan honorifik saling berhubungan satu sama lain. Honorifik adalah bagian dari politeness. Politeness adalah istilah untuk menunjukkan kesantunan dalam berbahasa sesuai dengan budaya dan situasi pemakaiannya. Menurut Leech (2014), politeness merupakan kesantunan berkomunikasi di antara individu dengan menghargai orang lain. Fenomena ini terjadi dalam kehidupan sosial yang melibatkan atribut sosial di dalamnya. Atribut sosial yang disebutkan Leech tersebut dalam penelitian ini ialah peran konteks sosial.

Hakikat honorifik sendiri ialah ujaran kesantunan yang berkaitan dengan status sosial, tenggang rasa, saling menghormati, atau kesantunan dengan mempertimbangkan perbedaan status di antara pelaku komunikasi (Ningsih, 2012, p.8). Honorifik biasanya berlandaskan pada dua dimensi, yaitu hubungan sosial dan pemakaian bahasa (pragmatik), hubungan vertikal dan horizontal (termasuk kekuasaan dan jarak, atau kekuasaan dan solidaritas). Sebagai contoh, pemakaian sapaan pak pada Pak Andi perlu mempertimbangkan hubungan vertikal antara penutur dengan orang yang bernama Andi, hubungan social di antara keduanya, hubungan horizontal, dan siapa yang memiliki kuasa (power) paling tinggi (Leech, 2014,p. 11).

Penelitian ini berhubungan dengan dua bidang linguistik yang berbeda yaitu pragmatik dan psikolinguistik. Dari bidang pragmatik terlihat dari struktural bahasa yang menempatkan bahasa Korea sebagai bahasa aglutinatif. Bahasa aglutinatif yaitu jenis bahasa yang memiliki banyak imbuhan atau penanda dalam gramatikalnya. Dalam bahasa aglutinatif tidak mengenal perubahan verba (infleksi dan derivasi). Penanda atau imbuhan pada bahasa aglutinatif juga berimbas pada sistem kesantunannya dan bentuk honorifik yang dinilai cukup rumit. Selain itu peran konteks dalam bahasa aglutinatif saling berdampingan satu sama lain, karena saat seseorang akan bertutur dalam bahasa aglutinatif akan ada pengolahan struktur kalimat dalam kognitifnya mengenai imbuhan atau penanda yangsesuai dengan konteks situasi tertentu. Hal inilah yang menempatkan bahasa Korea sebagai bahasa dengan konteks tinggi (Hall, 1976).

Dari bidang psikolinguistik meneliti mengenai kemampuan pemelajar dalam menguasai kesantunan bahasa Korea yang diujikan dalam penelitian ini. Pernyataan tersebut sekaligus menjadi rumusan masalah yang pertama, yaitu sejauh mana pemelajar Indonesia dalam menguasai kesantunan bahasa Korea. Rumusan masalah yang kedua ialah mengenai faktorfaktor yang sekiranya berperan dalam pemerolehan kesantunan bahasa Korea, dan yang terakhir ialah upaya-upaya yang mampu memfasilitasi pemelajar dalam pemerolehan kesantunan bahasa Korea.

Sistem honorifik yang digunakan dalam penelitian ini ialah sistem honorifik dari Ihm, Hong, \& Chang (2001). Sistem honorifik menurut Ihm terbagi menjadi tiga kategori besar yaitu penghormatan terhadap subjek (subject honorification), ragam tindak tutur (speech levels), dan bentuk honorifik dari makna leksikal ekspresi (bonorifications by means of lexical expressions).

Penghormatan kepada subjek ditandai dengan imbuhan -시 [-si] pada predikat. Ihm berpendapat bahwa faktor yang mempengaruhi penggunaan honorifik ini antara lain usia, jabatan dan status sosial. Seperti contoh beberapa verba yang diubah menjadi bentuk honorifik kepada subjek. 
Tabel 1. Verba dengan Sisipan -시

\begin{tabular}{|c|c|c|}
\hline Kata Dasar & Sisipan -시 & $\begin{array}{c}\text { Kata Dasar }+ \text { Sisipan }-a+- \\
\text { W }\end{array}$ \\
\hline | , & d & | $\mathrm{k}$ " $\quad$ [pergi] \\
\hline , & s d & s k " [bagus] \\
\hline$\dot{i}$, & ¿ d & $\dot{c} \mathrm{k}$ " [cantik] \\
\hline
\end{tabular}

(Sumber: Ihm, Hong, Chang, 2001,p.199-200)

Penggunaan imbuhan penghormatan terhadap subjek memiliki empat kondisi, yang nantinya akan menjadi syarat digunakan atau tidaknya imbuhan penghormatan - d [-si]. Mengapa disebut kondisi, karena penggunaan imbuhan terhadap subjek ini berkaitan dengan konteks yang menjadi latar belakang sebuah tuturan.

Kondisi pertama dalam penggunaan imbuhan penghormatan - d[-si] adalah jika status pendengar lebih tinggi dari pada subjek kalimat, dan status subjek kalimat lebih tinggi dari pada penutur. Maka tidak harus menggunakan imbuhan subjek ini. Kasus ini lebih sering terdengar sebagai percakapan. Contoh kontek kondisi pertama ialah sebagai berikut, [konteks bahasa Indonesia] seorang anak memberitahu neneknya bahwa kakak perempuannya baru saja pulang kerja $\rightarrow$ [kalimat bahasa Korea]

1 a " . Berikut ialah bagan singkat mengenai kondisi pertama ini (Bagan 1).

Bagan 1. Kondisi Pertama Penghormatan Terhadap Subjek

\section{Ketentuan Kelompok Pertama}

- Pembicara

Objek

Pendengar

(Sumber: Ihm, Hong, Chang, 2001,p. 200)

Kondisi dua dalam penggunaan imbuhan penghormatan - d[-si] adalah dalam genre kalimat berita (report) atau konteks ilmiah yang cenderung membahas ilmu pengetahuan. Maka tidak diharuskan menggunakan imbuhan penghormatan subjek. Contoh situasi yang mewakili syarat kedua ini ialah, [konteks bahasa Indonesia] 
Sebuah berita menayangkan bahwa Presiden Korea Selatan sedang mengunjungi Amerika Serikat dalam rangka kerja sama bidang ekonomi $\rightarrow$ [kalimat bahasa Korea] 대통령이 미국을 방문한다.

Kondisi tiga dalam penggunaan imbuhan penghormatan -시 [-si] adalah jika mengacu pada satu bagian khusus dari target honorifik (subjek kalimat), maka diharuskan menggunakan imbuhan subjek ini, sebagai bentuk dari indirect honorific effect. Salah satu contoh konteks dalam kondisi ini ialah Salah satu guru saya di sekolah hari ini tidak masuk karena terkena flu berat $\rightarrow$ [kalimat bahasa Korea] 선생님께서는 감기가 드셨습니다.
Kondisi empat sekaligus yang terahir dalam penggunaan imbuhan penghormatan -시[-si] adalah jika status dari target honorifik (subjek kalimat) lebih tinggi dari pendengar dan jika status penutur lebih tinggi dari pada pendengar. Maka diharuskan menggunakan imbuhan honorifik penghormatan subjek ini. Contoh situasi untuk kondisi empat ini ialah [konteks bahasa Indonesia] Ibu saya bertanya kepada adik saya yang masih berumur 5 tahun, bertanya mengenai suaminya yang sudah berangkat untuk kerja atau belum $\rightarrow$ [kalimat bahasa Korea] 영수야, 아버지 회사에 가셨니? Deskripsi singkat mengenai kondisi terakhir ini dapat terlihat pada bagan 2.

Bagan 2. Ketentuan Kondisi Keempat Penghormatan Terhadap Subjek

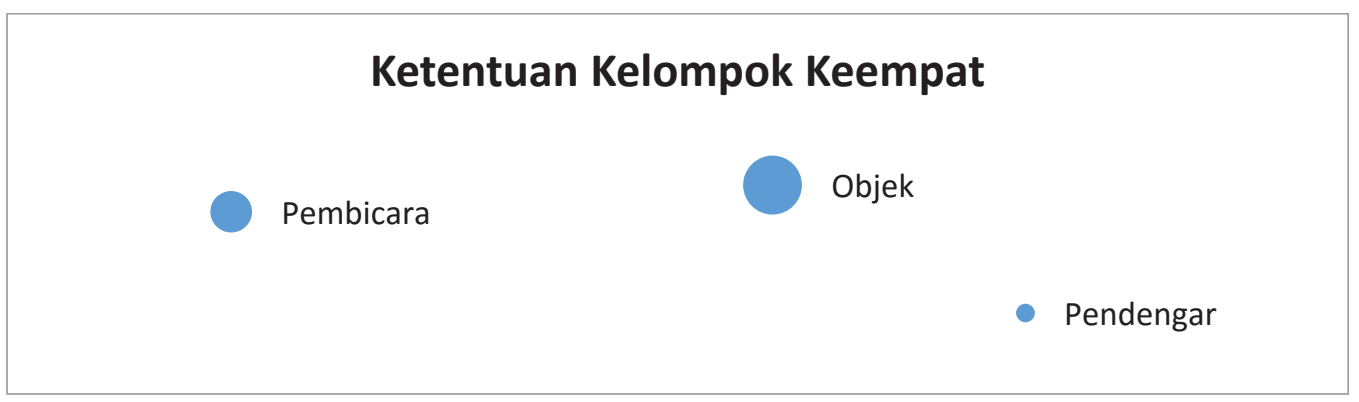

(Sumber: Ihm, Hong, Chang, 2001,p.202)

Setelah ditelaah lebih jauh lagi, penelitian ini hanya menggunakan dua kondisi saja yaitu kondisi (1) dan kondisi (4). Hal tersebut dilakukan karena kondisi tersebut dinilai akan menghasilkan konteks yang cukup serupa namun berbeda penggunaan. Jika kondisi (1) diharuskan menggunakan imbuhan penanda subjek, sedangkan kondisi (4) tidak diharuskan menggunakan imbuhan penanda subjek. Hal ini dilihat dari faktor keakraban penutur, pendengar dan objek yang dibicarakan. Dengan begitu, penelitian ini mengharapkan para pemelajar bahasa Korea dilatih untuk lebih sadar terhadap faktor keakraban tersebut.

Kategori honorifik yang kedua menurut Ihm, dkk dalam bukunya ialah ragam tindak tutur (speech levels) yang terbagi menjadi dua kelompok yaitu ragam formal, dan ragam informal. Ragam formal mencakup tiga ragam di dalamnya yaitu ragam formal tinggi, netral dan rendah. Berikut adalah tabel yang mencakup ragam formal dan ragam informal. 
Jurnal Pendidikan Bahasa dan Sastra, Volume 18, Nomor 2, Oktober 2018, pp. 174 - 192

Tabel 2. Ragam Tuturan Formal dan Informal

\begin{tabular}{|c|c|c|c|c|c|c|}
\hline \multicolumn{2}{|c|}{ Final Ending } & $\begin{array}{l}\text { Declarative } \\
\text {-ㅂ/습니다 }\end{array}$ & $\begin{array}{l}\text { Interrogative } \\
\text {-ㅂ/습니까 }\end{array}$ & \multirow{2}{*}{$\begin{array}{l}\text { Imperative } \\
\text {-(으)십시오 }\end{array}$} & \multirow{2}{*}{$\begin{array}{l}\text { Propositive } \\
\text {-(으)십시다 }\end{array}$} & \multirow{2}{*}{$\begin{array}{l}\text { Exclamatory } \\
\text {-는구료 } \\
\text {-구료 } \\
\text {-(이)로구료 }\end{array}$} \\
\hline \multirow{3}{*}{$\begin{array}{l}\text { Formal } \\
\text { Speech } \\
\text { Level }\end{array}$} & $\begin{array}{c}\text { Formal } \\
\text { High }\end{array}$ & $\begin{array}{l}\text {-ㅂ/습니다 } \\
\text {-(이)ㅂ니다 }\end{array}$ & $\begin{array}{l}\text {-ㅂ/습니까 } \\
\text {-(이)ㅂ니까 }\end{array}$ & & & \\
\hline & Neutral & $\begin{array}{l}\text {-네, -데, - } \\
(\text { 으)네 세, } \\
\text {-(으)이, } \\
\text {-(이)네, } \\
\text {-(이) 데, } \\
\text {-(이)르 세 }\end{array}$ & $\begin{array}{l}\text {-(으)니까, - } \\
\text { 는가, -던가, - } \\
\text { (으)르까, - } \\
(\text { 으)나, 가, } \\
\text { (이)ㄴㅏㅏ, - } \\
\text { (이)던가 }\end{array}$ & -게 & -세 & $\begin{array}{l}\text {-는구먼, - } \\
\text { 구먼, - } \\
\text { (이)구먼 }\end{array}$ \\
\hline & Low & $\begin{array}{l}\text { - ㄴ /는다, - } \\
\text { (더)라, - } \\
\text { 니나라, - } \\
\text { (으)리라, - } \\
\text { (으)마, -다, - } \\
\text { (으)니라, - } \\
\text { (더)라 }\end{array}$ & $\begin{array}{l}\text {-니, -느냐, - } \\
\text { (으) 니, -(으) 냐, - } \\
\text { (이) 니, -(이) 냐 }\end{array}$ & $\begin{array}{l}\text {-어 } \\
\text { (어,아)라, - } \\
\text { 너라, - 거라, } \\
\text {-(으)려머나, } \\
\text {-(으)렵 }\end{array}$ & $\begin{array}{l}\text {-자, -구나, - } \\
\text { (이)구나 }\end{array}$ & -는구나 \\
\hline \multirow[t]{2}{*}{$\begin{array}{l}\text { Informa } \\
1 \text { Speech } \\
\text { Level }\end{array}$} & $\begin{array}{c}\text { Informal- } \\
\text { High }\end{array}$ & $\begin{array}{l}\text {-어(아,어)요, } \\
\text {-지요, - } \\
\text { (이)지요, - } \\
\text { 이어/여요, - } \\
\text { (이)네요, - } \\
\text { (이)데요 }\end{array}$ & $\begin{array}{l}\text {-어(아,어)요, - } \\
\text { 지요, -(이)지요 }\end{array}$ & $\begin{array}{l}\text {-어(아,어)요, } \\
\text {-지요 }\end{array}$ & $\begin{array}{l}\text {-어(아,어)요, } \\
\text {-지요, - } \\
\text { 는군요, - } \\
\text { 군요, - } \\
\text { (이)군요, - } \\
\text { (이)로군요 }\end{array}$ & \\
\hline & $\begin{array}{l}\text { Informal- } \\
\text { Low }\end{array}$ & $\begin{array}{l}\text {-어(아,어), - } \\
\text { 지 }\end{array}$ & $\begin{array}{l}\text {-어(아,어), -지, - } \\
\text { (이)야, -(이)지 }\end{array}$ & $\begin{array}{l}\text {-어(아,어), - } \\
\text { 지 }\end{array}$ & $\begin{array}{l}\text {-어(아,어), - } \\
\text { 지, -(이)군,- } \\
\text { (이)로군 }\end{array}$ & -는군, -군 \\
\hline
\end{tabular}

(Sumber: Ihm, Hong, Chang, 2001,p.203-204) 
Kategori honorifik ketiga menurut Ihm, dkk adalah bentuk honorifik dari makna leksikal ekspresi (bonorifications by means of lexical expressions). Bentuk ini adalah bentuk lain dari beberapa kata verba atau kata benda dari bahasa Korea. Yang dimaksud dengan 'bentuk lain' adalah adanya leksikal lain yang memiliki arti yang serupa dan diaplikasikan khusus pada kasus honorifik. Berikut adalah tabel mengenai beberapa kelas kata yang memiliki bentuk leksikal lain, namun memiliki arti yang serupa.

Tabel 3. Honorification by Means of Lexical Expressions

\begin{tabular}{llll}
\hline \multicolumn{1}{c}{ Kelas Kata } & \multicolumn{1}{c}{ Pola Informal } & Pola Honorifik & Pola Hormat \\
\hline Kata Benda & $\begin{array}{l}\text { 말, 나이, 밥, 병, 말씀, 연세, 진지, 말씀 } \\
\text { 집. } \\
\text { 병환, 댁 }\end{array}$ & \\
\hline Kata Ganti & 그사람, 나, 우리 & 그분 & 저, 저희 \\
\hline Kata Kerja & 주다, 보다, 자다, 드리다, 뵙다, & \\
& 먹다, 있다 & 주무시다, \\
& & 잠수시다, 계시다 & \\
& -이/가, -에게 & -께서, -께 \\
\hline Partikel & & -님
\end{tabular}

(Sumber: Ihm, Hong, Chang, 2001,p.210-211)

Dengan demikian, teori milik Ihm, Hong, Chang (2001) ini akan menjadi dasar pembuatan instrumen dan pengambilan data kepada informan. Namun, kategori yang akan digunakan hanya kategori penghormatan terhadap subjek (subject bonorification), yang dinilai menjadi kategori yang lebih sedikit variasinya.

\section{METODE}

Metode yang digunakan dalam penelitian ini ialah metode kualitatif. Metode kualitatif berfokus pada sebuah proses atau bagaimana sesuatu terjadi (Moleong, 2006,p.7-11). Selain itu, metode kualitatif erat kaitannya dengan huruf dan penjelasan atau deskripsi. Metode ini mendeskripsikan suatu data menggunakan kalimat atau narasi. Metode kualitatif juga penelitian yang bertujuan mencari pola atau struktur, karakteristik dan atau kualitas dari sebuah teks (data) sebagai dasar untuk menarik kesimpulan atau hasil penelitian (Rasinger dalam Litosseliti 2010,p.52). Oleh karena itu penelitian ini juga disebut penelitian deskriptif kualitatif.

Subjek dalam penelitian ini adalah pemelajar tingkat lanjut bahasa Korea (selanjutnya akan disebut dengan informan) yang terdaftar sebagai anggota komunitas HKLCB yang berjumlah 20 informan, berlatar belakang budaya Sunda, berusia diantara 18-31 tahun. Profesi para informan berkutat diantara penerjemah lisan dan tulisan bahasa Korea, pengajar bahasa Korea, mahasiswa sastra bahasa, dan pegawai swasta. Keberagaman profesi dan umur para informan menandakan tingginya pengaruh bahasa Korea pada seluruh 
kalangan. Rata-rata waktu lama belajar seluruh informan ialah 5,3 tahun, dengan intensitas belajar yang berbeda-beda. Pemilihan subjek penelitian termasuk dalam kriteria informan non-mobile yaitu kriteria informan yang lama menetap di suatu tempat dan tidak berpindah-pindah, sehingga di asumsikan tidak ada pengaruh luar yang cukup berpengaruh (Djajasudarma, 2010,p.21-26).

Instrumen tes yang digunakan meliputi tes membaca, berjumlah 20 soal. Tes yang diujikan terdiri dari konteks bahasa Indonesia dan pernyataan dalam bahasa Korea. Dari keduapuluh soal terdapat delapan konteks yang berbeda dan 16 pernyataan bahasa Korea. Empat soal lainnya berfungsi sebagai pengecoh (lihat lampiran).

Tata cara dalam mengerjakan tes ini, para informan akan menentukan kecocokan antara konteks bahasa Indonesia dengan pernyataan bahasa Korea. Pada tes soal, akan ada pilihan 'berterima' (B) jika informan merasa pernyataan bahasa Korea dan konteks bahasa Indonesia cocok satu sama lain,dan 'tidak berterima' (TB) jika informan merasa tidak cocok antara pernyataan dan konteks.

Selain menggunakan instrumen tes, penelitian ini menggunakan instrumen nontes yang berupa wawancara. Instrumen nontes digunakan untuk mengetahui opini para subjek penelitian mengenai instrumen tes honorifik yang sudah dilakukan sebelumnya. Penelitian ini menggunakan teknik pengambilan data berupa wawancara sebagai teknik penunjang dari teknik sebelumnya. hasil dari wawancara akan menjadi data pendukung dalam pemerolehan honorifik bahasa Korea. Pertanyaan yang akan muncul dalam setiap wawancara kepada subjek penelitian antara lain,

Tabel 4. Panduan Wawancara

\section{Pokok Pertanyaan terhadap Pemelajar Tingkat Lanjut}

1. Mengenai imbuhan honorifik 으시, sudah mengerti sepenuhnya?

2. Kira-kira hal apa saja yang paling sulit dalam menguasai partikel으시 ini?

3. Kira-kira punya cara tertentu tidak untuk menguasai partikel 으시 ini?

4. Pernah dengar istilah task-essentialness, task-based teaching, pola eliminasi, pola imersi dalam bahasa Korea? Jika pernah, apakah ada pengaruhnya dalam pembelajaran honorifik?

\section{HASIL DAN PEMBAHASAN}

Berdasarkan rumusan masalah pertama mengenai sejauh mana pemerolehan honorifik bahasa Korea oleh informan menghasilkan skor tertinggi yang di dapat ialah 95 poin, diraih oleh satu informan.
Sedangkan skor yang terendah ialah 45 point, diraih oleh satu informan juga. Hasil nilai keseluruhan menghasilkan rata-rata yaitu 70,5 poin dan standar deviasi sebesar 13,85 poin. Nilai masing-masing informan akan dijelaskan pada bagan berikut, 
Diagram 1. Data Nilai Para Informan

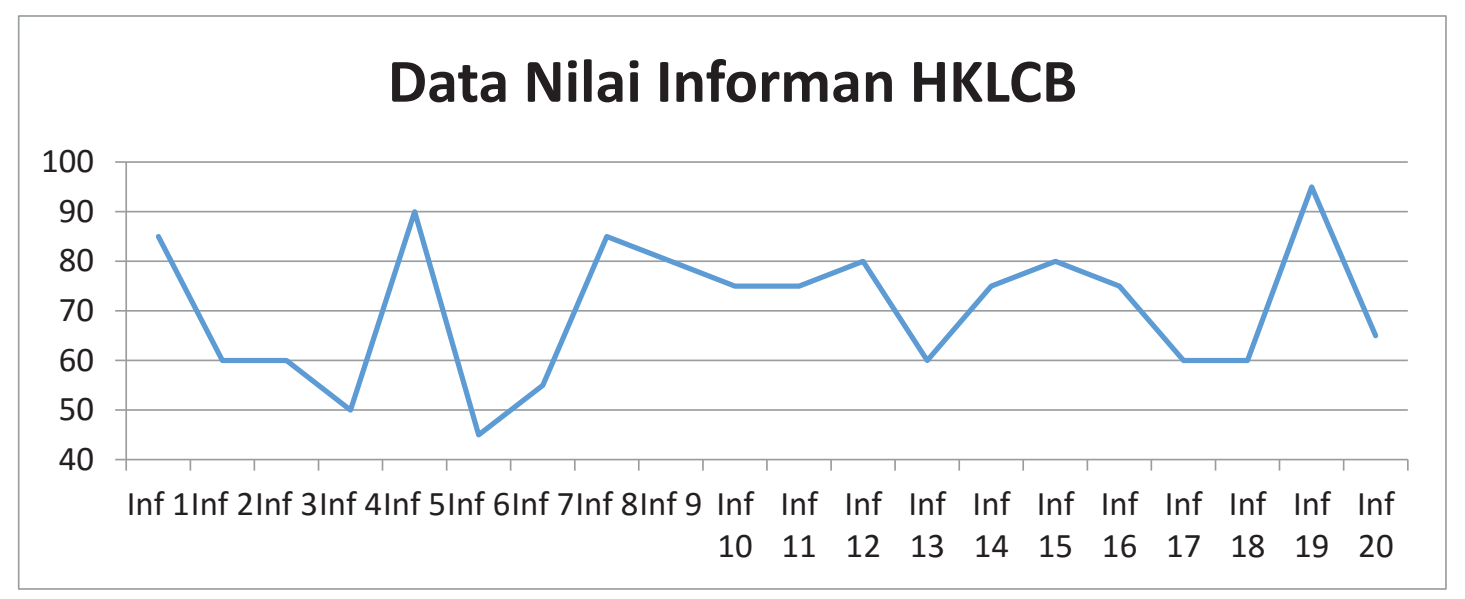

Selain menggunakan tabel, nilai informan akan ditampilkan dalam bentuk persentase dan frekuensi. Hal ini bertujuan sering muncul dan seberapa banyak nilai untuk memperlihatkan nilai yang paling tersebut muncul.

Tabel 5. Persentase dan Frekuensi Nilai Informan

\begin{tabular}{ccc}
\hline \multicolumn{3}{c}{ Nilai Informan } \\
\hline Skor & F & $\%$ \\
\hline 45 & 1 & $5 \%$ \\
\hline 50 & 1 & $5 \%$ \\
\hline 55 & 1 & $5 \%$ \\
\hline 60 & 5 & $25 \%$ \\
\hline 65 & 1 & $5 \%$ \\
\hline 70 & 0 & $0 \%$ \\
\hline 75 & 4 & $20 \%$ \\
\hline 80 & 3 & $15 \%$ \\
\hline 85 & 2 & $10 \%$ \\
\hline 90 & 1 & $5 \%$ \\
\hline 95 & 1 & $5 \%$ \\
\hline 100 & 0 & $0 \%$
\end{tabular}

Pada tabel 5. terdapat dua nilai yang paling banyak diraih oleh informan yaitu nilai 60 dan nilai 74. Kedua nilai ini bukan nilai yang terendah maupun yang tertinggi, namun dapat menjadi gerbang nilai terendah dan tertinggi. Kedua nilai ini memiliki persentase sebesar $25 \%$ dan $20 \%$.

Selanjutnya ialah mengenai konteks dan soal yang memiliki persentase kesalahan tertinggi dan terendah diantara nilai para informan. Dimulai dari konteks yang memiliki presentasi paling tinggi tingkat kesalahannya yaitu konteks no.2 pada kondisi (1) dengan total persentase 115\% (gabungan dari dua nomor). Fakta ini sekaligus mampu menempatkan konteks no.2 menjadi konteks yang paling sulit dijawab atau yang paling membingungkan informan. Data selengkapnya terangkum dalam tabel berikut. 
Jurnal Pendidikan Bahasa dan Sastra, Volume 18, Nomor 2, Oktober 2018, pp. 174 - 192

Tabel 6. Konteks dengan Persentase Kesalahan Tertinggi

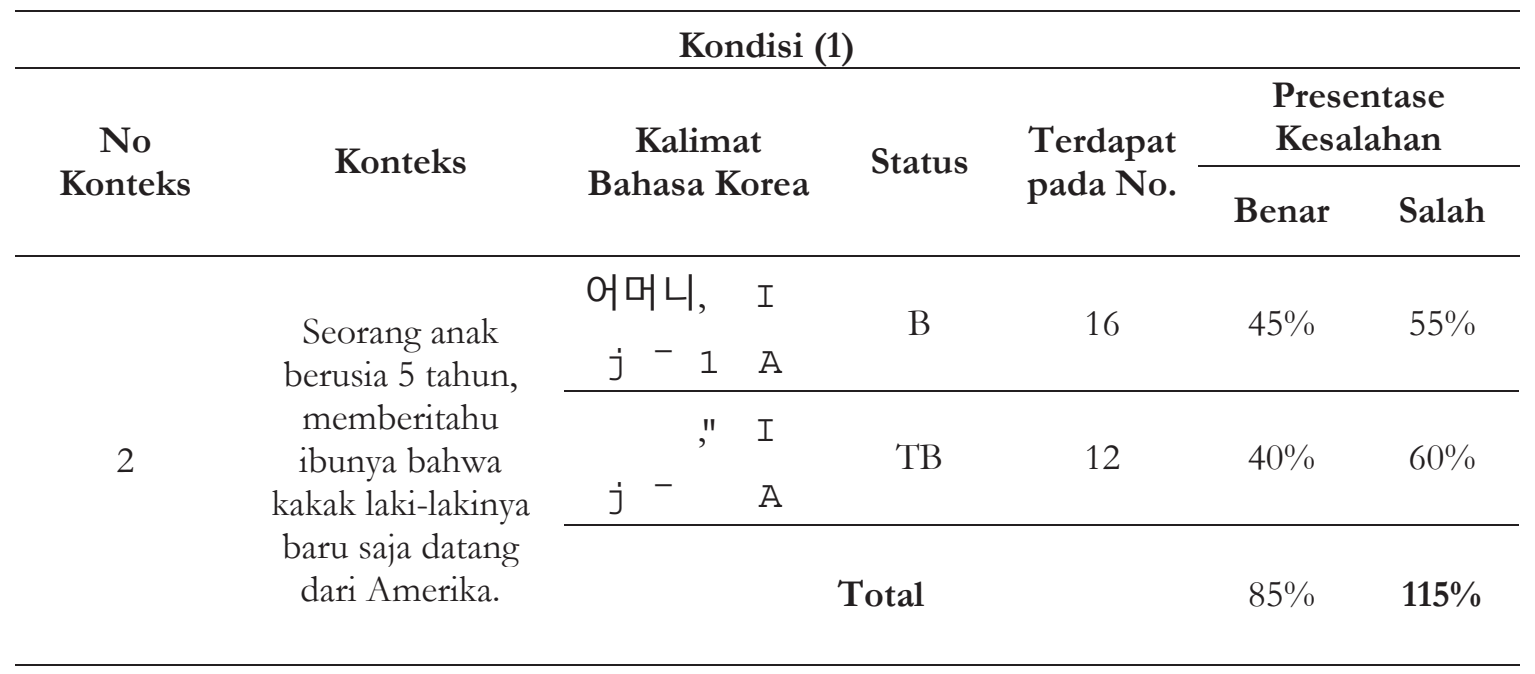

Pada tabel 6. memperlihatkan jumlah persentase kesalahan pada konteks no.2 kondisi (1). Salah satu wawancara informan mengenai konteks ini, menyebutkan bahwa yang menjadi sulit dalam konteks ini adalah pernyataan konteks itu sendiri. Para informan merasa terkecoh dengan kedua pernyataan bahasa Korea yang ada dalam konteks no.2 ini. Adapula yang menganggap kedua pernyataan bahasa Korea dalam konteks ini dapat digunakan keduanya. Oleh karena itu, selisih kesalahan antara kedua pernyataan cukup tipis yaitu sebesar 5\% (60\%-55\%).

Sedangkan soal dengan persentase kesalahan tertinggi menurut informan ialah soal no. 12. Soal ini menghasilkan persentase kesalahan terbesar $60 \%$, berada dalam konteks no. 2 kondisi 1.

Setelah membicarakan mengenai konteks dan soal persentase tertinggi, beralih pada konteks dan soal persentase terendah. Konteks yang memiliki presentasi paling rendah tingkat kesalahannya yaitu konteks no.4 kondisi (1) sebesar 10\%. Fakta ini sekaligus mampu menempatkan konteks no.4 menjadi konteks yang paling mudah dijawab atau yang paling meringankan informan. Data selengkapnya terangkum dalam tabel berikut.

Tabel 7. Konteks dengan Persentase Kesalahan Terendah

\begin{tabular}{ccccccc}
\hline \multicolumn{1}{c}{ Kondisi (1) } \\
\hline $\begin{array}{c}\text { No } \\
\text { Konteks }\end{array}$ & Konteks & $\begin{array}{c}\text { Kalimat } \\
\text { Bahasa Korea }\end{array}$ & Status & $\begin{array}{c}\text { Terdapat } \\
\text { pada } \\
\text { No. }\end{array}$ & \multicolumn{2}{c}{$\begin{array}{c}\text { Persentase } \\
\text { Kesalahan }\end{array}$} \\
\hline 4 & $\begin{array}{l}\text { Seorang siswa } \\
\text { memberitahu } \\
\text { kepada salah } \\
\text { satu gurunya }\end{array}$ & 9 & Benar & Salah \\
\hline
\end{tabular}




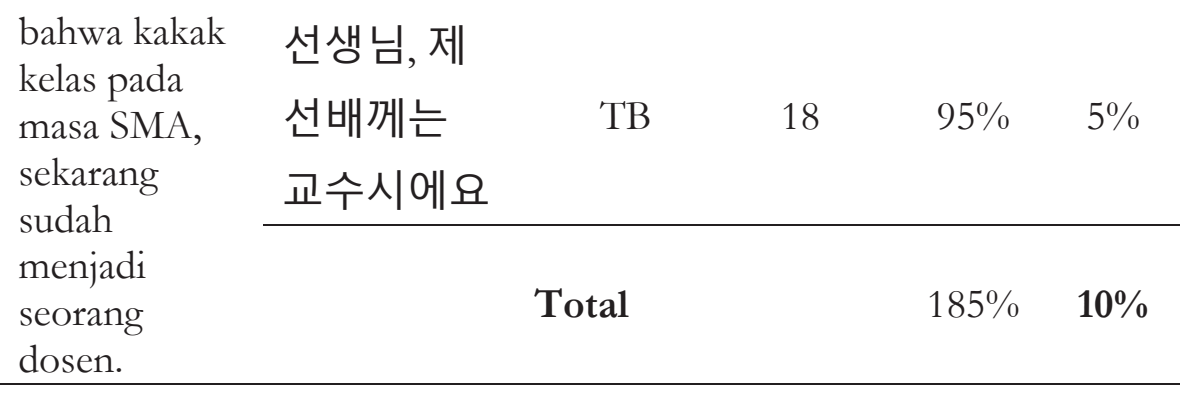

Pada tabel 7. memperlihatkan jumlah persentase kesalahan pada konteks no.4 kondisi (1). Seluruh informan yang menjawab keliru hanya sebanyak 10\% saja. Persentase tersebut tersebar pada dua no yaitu no. 11 dan no. 18 , yang masing-masing memiliki $5 \%$ kesalahan. Temuan ini sekaligus menjadikan no. 11 dan no. 18 menjadi soal dengan persentase kesalahan terendah.

\section{Faktor-Faktor dalam Pemerolehan Honorifik Bahasa Korea}

Pada rumusan masalah yang kedua mengenai faktor-faktor, menggunakan wawancara sebagai instrumen pemerolehan data. Para informan diwawancara setelah mengerjakan instrumen tes soal pada waktu yang sama namun tempat yang berbeda. Faktor-faktor penentu yang dideskripsikan pada penelitian ini mengutip dari buku milik Chaer (2015). Dalam bukunya, Chaer menjelaskan ada lima faktor penentu dalam pemerolehan bahasa kedua yaitu faktor motivasi, faktor usia, faktor penyajian formal, faktor bahasa pertama, dan faktor lingkungan. Namun dalam penelitian ini hanya ditemukan beberapa faktor yang mendukung Chaer.

Faktor pertama yang ditemukan dalam penelitian ini ialah faktor bahasa pertama. Berdasarkan wawancara, beberapa informan mengaku kesulitan dalam menguasai honorifik Korea disebabkan pada bahasa Indonesia tidak memiliki sistem kesantunan seperti bahasa Korea. Begitupun dengan bahasa Sunda, walaupun bahasa Sunda memiliki unsur kesantunan yang hampir serupa, namun dalam bahasa
Sunda tidak ada partikel penanda khusus kesantunan yang dilekatkan pada verba kalimat. Hal ini yang menyebabkan terhambatnya pemerolehan pemelajar terhadap honorifik Korea.

Sebab yang lainnya ialah adanya bonorific forms atau undak usuk bahasa Korea yang tidak memiliki pola dan harus dihafal masing-masing informan. Seperti dalam bahasa Indonesia kalimat "sudikah anda", dan bahasa Sunda seperti, "tuang, neda", dan lain sebagainya, ungkapan-ungkapan tersebut digunakan hanya pada situasi tertentu saja.

Hasil wawancara pada pemelajar memunculkan fakta bahwa bonorific forms berpengaruh dalam penguasaan honorifik. Seperti halnya salah satu informan menyebutkan bahwa, hal yang paling sulit dari menguasai imbuhan _시ini adalah banyaknya kata (leksikal) yang bermakna serupa. Dengan demikian berbagai macam honorific forms akan menjadi urusan tersendiri dalam menguasai bidang honorifik bahasa Korea.

Faktor berikutnya ialah faktor lingkungan. Yang dimaksud dengan lingkungan bahasa adalah segala sesuatu yang didengar dan dilihat oleh pemelajar sehubungan bahasa kedua yang sedang dipelajari, seperti situasi di restoran atau toko, saat melakukan percakapan dengan teman, ketika menonton televisi, dan sebagainya (Tjohjono, dalam Chaer, 2015,p.258). Kualitas lingkungan bahasa ini merupakan sesuatu yang sangat penting bagi informan untuk memperoleh keberhasilan dalam mempelajari bahasa 
kedua. Faktor lingkungan kali ini berkaitan erat dengan intensitas informan dalam menggunakan bahasa Korea.

\section{Penjelasan mengenai faktor} intensitas ini dilandasi oleh hasil wawancara terhadap tiga informan peraih nilai tertinggi dan nilai terendah. Faktor intensitas ini nantinya akan berhubungan dengan salah satu upaya pedagogik. Hal yang mencolok dari tiga informan tertinggi dan terendah ialah profesi pekerjaan mereka. Tiga informan tertinggi berkutat dengan bahasa Korea dalam profesinya, seperti contoh penerjemah lisan dan tulisan, pendidik bahasa Korea, dan lainnya, serta ketiga informan ini sudah terbiasa dengan kondisi bahasa Korea yang kompleks. Sedangkan tiga informan terendah, menyentuh bahasa Korea hanya pada saat pembelajaran kelas saja. Dengan begitu, perbedaan yang cukup jelas terlihat diantara keduanya. Satu kelompok dengan intensitas penggunaan bahasa Korea yang tinggi, dan satu kelompok lainnya dengan intensitas penggunaan yang rendah.

Dengan begitu, faktor-faktor penentu pemerolehan bahasa kedua pada penelitian ini hanya ditemukan dua faktor saja (berdasarkan kategori faktor Chaer) yaitu faktor bahasa pertama, dan faktor lingkungan. Faktor lainnya tidak ditemukan karena tidak di uji dalam penelitian ini.

\section{Upaya-upaya berbasis Pedagogik}

Upaya-upaya berbasis pedaogik yang ada pada pembahasan kali ini berdasarkan kutipan dari jurnal milik Mueller dan Jiang (2013). Upaya-upaya tersebut adalah taskessentialness, task-based teaching, pola eliminasi, pola imersi, dan penggunaan media. Subbab ini akan menjelaskan kelima upaya tersebut satu persatu. Seluruh informan sudah mencoba upaya-upaya ini, dan data wawancara menunjukkan upaya seperti apa yang paling berpengaruh dalam proses pemerolehan bahasa kedua.

Upaya pertama dalam jurnal Mueller dan Jiang (2013) ialah task- essentialness. Task-essentialness itu sendiri terdiri dari tugas-tugas berbasis pedagogik yang mampu menjamin kesuksesan akan pemahaman dan praktek (lisan) pemelajar terhadap ketelitian suatu struktur (bahasa). Keberhasilan task-essentialness dalam praktek lisan terlihat dari adanya balasan yang didapat saat berdialog. Salah satu contoh tugas yang berbasis pedagogik ini tentunya bermacam-macam, seperti contoh tugas teori ataupun tugas praktek. Tugas teori dapat berupa tugas menjawab pertanyaan secara tertulis, tugas persentase mengenai satu bidang, ataupun tugas tulisan. Sedangkan tugas prakter, erat kaitannya dengan tugas lisan, tugas wawancara, percakapan, dialog, dan lain sebagainya.

Upaya selanjutnya ialah task-based teaching. Upaya ini dipelopori oleh Van Patten's (2002), proses pemerolehan melalui task-based teaching memiliki unsur pedagogik didalamnya, dalam beberapa pandangan, terlihat mirip dengan teknik sebelumnya yaitu task-essentialness. Kedua upaya ini berasaskan tugas sebagai media evaluasi setelah materi. Perbedaanya ialah task-based teaching lebih umunya disebut tugas rumah atau pekerjaan rumah (PR). Jika task-essentialness ialah tugas yang berkonteks lebih umum (seluruh jenis tugas), sedangkan task-based teaching lebih khusus hanya tugas yang dikerjakan di luar pembelajaran kelas. Dalam proses pemerolehan, pemerolehan ialah suatu struktur mengenai pola bahasa tujuan yang harus diikuti para pemelajar demi menyelesaikan tugas pembelajaran. Honorifik bahasa Korea dapat menjadi contoh yang ideal dalam pembelajaran berbasis task-based teaching.

Upaya ketiga ialah mengenai pola/sistem eliminasi dalam struktur bahasa Korea. Dalam bahasa Korea terdapat sistem eliminasi subjek ataupun objek. Dalam beberapa konteks, jika suatu kalimat dilibatkan subjeknya, maka imbuhan honorifik akan diacuhkan oleh para pemelajar. Mereka akan lebih fokus terhadap subjek dan makna umum seluruh 
kalimat. Seperti contoh, 이 선생님, 빨리 2층에 오세요 'guru Lee, tolong cepat datang ke lantai 2'. Subjek kalimat tersebut adalah guru Lee (yang dicetak miring), maka mayoritas pemelajar tidak memperdulikan imbuhan honorifik, mereka hanya akan berfokus pada subjek (apakah harus hormat atau tidak). Pada kasus lain, jika sebuah kalimat tidak memunculkan subjeknya, maka para pemelajar akan mencari petunjuk lain dalam kalimat tersebut (gambar individu dewasa atau anak kecil yang sedang membaca buku). Petunjuk penting tersebut digunakannya agar memahami makna. Contoh kalimatnya ialah, 빨리 2층에 오세요 'tolong cepat datang ke lantai 2'. Kalimat tersebut tidak memunculkan subjek didalamnya, para pemelajar akan mencari petunjuk lain sebagai pengganti subjek, dalam hal ini adalah kata오세요 [ose-yo] 'tolong datang' yang merupakan petunjuk kesantunan. Dengan cara latihan seperti ini mampu meningkatkan kemampuan pemerolehan bahasa kedua layaknya penutur asli, bukan seperti mekanisme bahasa pertama mereka.

Upaya keempat ialah mengenai imersi. Dalam pemelajaran bahasa kedua ada istilah imersi yang berdefinisi pembelajaran satu atau lebih bidang studi dengan menggunakan bahasa target sebagai media pembelajaran. Dan menurut Mueller dan Jiang (2013) pembelajar yang tidak melalui pembelajaran berbasis imersi, dinilai akan gagal membedakan berbagai status dan intiminasi bahasa Korea dalam berbagai konteks serta bermacam mitra tutur (seperti, dewasa berbicara kepada anak-anak dan pegawai berbicara dengan atasannya), dan tentunya hal ini berkaitan erat dengan bidang honorifik. Selain itu, terdapat situasi yang sering menimbulkan kesalahan pemelajar, ialah situasi kelas. Dimana situasi yang selalu menggunakan imbuhan honorifik dalam posisi yang serupa (imbuhan selalu digunakan jika guru berposisi sebagai subjek).
Upaya terakhir yang dipaparkan dalam jurnal milik Mueller dan Jiang (2013) ini ialah media hiburan Korea. Seperti yang telah diketahui bahwa media hiburan Korea (film, musik, budaya, dan lain sebagainya) telah merebak luas pada hampir seluruh lapisan sosial masyarakat Indonesia. Media hiburan Korea ini dinilai mampu menajdi media pembelajaran dalam membantu pemelajar menguasai honorifik bahasa Korea, dengan mengamati percakapan dalam film atau drama Korea. Dikarenakan saat ini film dan drama Korea sangat meluas di Indonesia, para pemelajar dapat menjadikan film dan drama ini sebagai media pembelajaran. Media dalam hal untuk memahami beragam status sosial, usia, power dan keakraban yang ada dalam kehidupan Korea. Untuk tingkat pembelajaran lebih lanjut, film dan drama ini dinilai mampu menggambarkan suatu pola (tatabahasa, honorifik, dll) dalam pergantian gaya (situasi). Yang pada akhirnya mampu menggunakan honorifik Korea dalam berbagai situasi yang berbeda.

Kesimpulan sederhana dari subbab ini ialah media hiburan Korea ternyata sangat digandrungi oleh seluruh pemelajar tingkat lanjut, untuk task-essentialness dan task-based teaching, menjadi upaya paling dasar dalam pembelajaran berbasis kelas, serta sistem eliminasi dan imersi menjadi upaya terdengar asing ditelinga para pemelajar. Kelima upaya ini mampu menjadi rekomendasi bagi pendidik Korea dalam membantu pemelajar menguasai honorifik, khususnya mengenai imbuhan honorifik - 시.

Pembahasan pada penelitian ini diawali dari temuan umum pada kelompok pemelajar, sekaligus menjadi temuan pokok dalam penelitian ini. Hasil rata-rata nilai instrumen tes para pemelajar tingkat lanjut ini sebesar 70,5 poin. Menurut Hatch dan Farhady (1982) dalam buku Research Design and Statistics for Applied Linguistics mengatakan bahwa, dalam skala skor 100, skor 0-50 tergolong rendah, skor 51-80 
tergolong cukup dan skor 81-100 tergolong tinggi. Maka dari itu, skor rata-rata para pemelajar pada penelitian ini tepat berada di garis awal tahap lanjut.

Temuan ini langsung mendukung pendapat Song (2005) dalam buku The Korean Language, Struktur, Use and Context. Song berpendapat bahwa sistem kesantunan bahasa Korea menjadi salah satu bidang yang sulit dipelajari dan bahkan menjadi area yang paling sering menghasilkan kesalahan pemelajar bahasa kedua (learner's errors). Serta menurut Sorace (Belleti dan Leonini, 2004; Sorace, 2005; Tsimpli dan Sorace, 2006; Valenzuela, 2006) bahwa bidang sintak pragmatik menjadi bidang yang sering menimbulkan kesulitan besar dan sering membuat proses pemerolehan tertunda lama, terutama pada pemelajar dewasa. Dua pendapat ini menjadi dasar pada hasil penelitian karena nilai rata-rata para informan memperlihatkan hal yang serupa, yaitu poin yang kurang tinggi, 70,5 poin.

Dengan skor 70,5, para informan dinilai belum mampu menjawab pertanyaan mengenai kesulitan pemelajar bahasa kedua tingkat lanjut akan morfem tatabahasa (Guillelmon \& Grosjean, 2001; Jiang, 2004, 2007; Lardiere, 1998; Long, 2003). Pertanyaan yang dipertimbangkan ialah apakah para pemelajar sudah meraih tingkat yang 'mendekati penutur' dalam pengembahan morfem tatabahasa (imbuhan honorifik). Terdapat tiga asumsi yang memungkinkan mereka sudah meraihnya. Pertama, seluruh pemelajar sudah meraih nilai cukup tinggi dalam ujian terakhir sebelum menuju kelas tingkat lanjut ini. Kedua, bahasa Jepang, bahasa Korea dan bahasa-bahasa yang ada di pulau Jawa, dalam hal ini latar belakang bahasa penutur ialah bahasa di pulau Jawa (bahasa Sunda), seluruhnya memiliki sistem honorifik yang sederhana dan secara langsung. Singkatnya para pemelajar sudah dibekali pengetahuan sistem honorifik bahasa Sunda, yang relatif serupa dengan bahasa Korea. Yang terakhir, seperti menurut Lardiere (1998) dan Long
(2003) mengungkapkan bahwa pembelajar bahasa kedua tingkat lanjut mayoritas menunjukkan tingkat signifikansi yang berbeda antara kemampuan teori dan kemampuan praktek. Kenyataannya, penelitian ini hanya mengambil ranah kemampuan teori saja, dengan hasil ratarata skor 70,5 poin, yang menempatkan para pemelajar belum sampai pada tingkat 'siap' dalam memahami imbuhan honorifik -시.

Pendapat lainnya ditemukan pada jurnal The Acquisition of Teh and Mab by The L2 Learners of Sundanese milik Kurniawan (2013) yaitu, informan dinilai akan semakin mudah memahami pragmatik pada bahasa kedua jika bahasa ibu dan bahasa kedua memiliki kesamaan struktur pragmatik yang cukup banyak, dalam hal ini struktur kesantunan. Pendapat ini sejalan dengan latar belakang bahasa para informan yang tidak lain ialah bahasa Sunda. Namun jika disandingkan dengan bahasa ibu para pemelajar yaitu bahasa Indonesia, pendapat ini tidak sejalan. Hal ini dikarenakan dalam bahasa Indonesia tidak memiliki sistem honorifik yang kompleks seperti bahasa Sunda dan bahasa Korea.

Temuan selanjutnya beralih pada salah satu temuan yang cukup menarik yaitu berpengaruhnya konteks dalam pemerolehan honorifik ini. Para informan sering terkecoh dalam kondisi dimana status sosial penutur lebih rendah dibanding mitra tutur, secara otomatis jenis kalimat yang dipakai ialah jenis kalimat formal. Selanjutnya para informan dirasa harus menyisipkan imbuhan honorifik pada kalimat yang terlihat formal tersebut. Namun pada nyatanya kondisi yang dijelaskan tersebut tidak mengaharuskan adanya imbuhan honorifik. Seperti halnya dalam jurnal Learning Context and Its Effects on Second Language Acquisition milik Collentine dan Freed (2004) yang mengatakan bahwa kunci dalam mempelajari bahasa dalam konteks ialah bukan diawali melalui bahasa namun melalui konteks, yang pada akhirnya akan 
berkaitan satu sama lain secara terstruktur. Dalam pemerolehan dan penguasaan bahasa kedua sangat penting untuk mempertimbangkan interaksi dalam aktifitas sosial serta elemen-elemen psikolinguistik. Jika bahasa tujuan tergolong dalam bahasa konteks sensitif, maka fase memahami konteks termasuk dalam pembahasan bahasa tingkat lanjut.

Lemahnya sensitifitas terhadap konteks, dipicu oleh kurangnya latihan, atau minimnya pengetahuan para pemelajar terhadap bidang honorifik ini. Interpertasinya ialah pada saat penjelasan mengenai honorifik ini, tidak seluruh pemelajar mengerti dengan sempurna, penjelasan honorifik tidak diulas secara lebih mendalam hanya permukaannya saja, dan atau para pemelajar memang sebelumnya belum pernah mendapatkan penjelasan honorifik. Sedangkan menurut Byon (2006), pembelajar bahasa Korea diharuskan memiliki empat kemampuan dasar ini. 1) bagaimana elemen-elemen linguistik honorifik seperti personal deiksis, honorifik leksikal, honorifik mitra tutur dan honorifik objek tersusun secara seimbang dan berterima (keberterimaan honorifik). 2) bagaimana unsur pragmatik ikut serta dalam penggunaan honorifik (kompetensi strategi). 3) memiliki pengetahuan mengenai sosio-kultural Korea (kompetensi fungsional dan sosiolinguistik). Dan 4) bagaimana faktor sosio-kultural-politis mempengaruhi penggunaan bahasa (penggunaan honorifik). Kesimpulannya, mengapa para pemelajar tingkat lanjut belum mencapai 'tahap siap' dalam bidang honorifik, salah satu faktornya bisa berasal dari pendidik mereka yang kurang kompeten dan kurang pengetahuan mengenai honorifik bahasa Korea.

Adapula keterhubungan antara faktor dan upaya yang sudah dijelaskan sebelumnya pada subbab Hasil, yaitu faktor intensitas dan upaya imersi. Pembahasan mengenai profesi dan intensitas dapat dihubungkan dengan buku milik Harley (2005) yang berjudul The Psychology of
Language, From Data to Theory Psychology Press. Pada buku tersebut disebutkan bahwa salah satu cara agar membuat pemerolehan bahasa kedua lebih mudah ialah dengan metode imersi, dengan tujuan memperluas pengetahuan mengenai bahasa kedua. Pada titik inilah faktor dan upaya saling berkaitan satu sama lain. Metode imersi adalah salah satu upaya berlandaskan pedagogik yang sudah dibahas sebelumnya, yaitu metode dimana para pemelajar mempelajari beberapa bidang dengan bahasa tujuan sebagai media pengantarnya. Dengan digunakannya bahasa Korea dalam profesi pemelajar salah satu bentuk dari metode imersi, tidak hanya berpaku pada suasana pembelajaran kelas namun menggunakannya dalam kegiatan seharihari yaitu profesi.

\section{SIMPULAN}

Penelitian ini berusaha mengungkap kebenaran dari pendapat para ahli seperti Song (2005) dan Sorace (2005) yang menyebutkan bahwa bidang kesantunan khususnya pada bahasa Korea ialah bidang yang paling sulit dikuasai para pemelajar asing. Hasil dari penelitian ini mendukung para pendapat ahli tersebut. Menurut Hatch dan Farhady (1982), dengan diraihnya skor rata-rata 70,5 poin, menempatkan para informan pada kategori "cukup" (kategori yang tidak sesuai dengan kelas tingkat lanjut) dalam menguasai atau bahkan menggunakan honorifik bahasa Korea. Hasil ini tentunya dipengaruhi oleh banyak faktor, diantaranya faktor intensitas dan faktor masuknya media Korea ke Indonesia. Saran yang dapat diambil dari penelitian ini ialah ruang lingkup penelitian ini masih tergolong sempit dan dapat diperluas lagi oleh penelitian selanjutnya.

\section{DAFTAR RUJUKAN}

Belleti, A., \& Leonini, C. (2004). Subjecti Inversion in L2 Italian. EUROSLA Yearbook, 4. 95-118.

Byon, A.S. (2006). Teacbing Korean Honorifics. Manoa: University of Hawaii. 
Chaer, A. (2015). Psikolinguistik: Kajian Teoritik. Jakarta: Rineka Cipta

Collentine, J., \& Freed, B. F. (2004). Learning Context and Its Effect on Second Language Acquisition. SSLA, 26, 153-171. Cambridge University Press.

Djajasudarma, F. T. (2010). Metode Linguistik. Ancangan Metode Penelitian dan Kajian. Refika Aditama.

Ellis, R. (1997). Second Language Acquisition. $2^{\text {nd }}$ Edition. New York. Oxford University Press.

Hall, E.T. (1976). Beyond Culture. New York: Anchor Press.

Harley, T. (2005). The Psychology of Language. (edisi ke-2). Hove and New York:

Psychology Press.

Ihm, H. B, Hong, K. P, \& Chang, S.I. (2001). Korean Grammar for International

Learners. Seoul: Yonsei University Press.

Jiang, N. (2004). Morphological Insensitivity in Second Language Processing. Applied

Psycholinguistics, 25, 603-634.

Kurniawan, E. (2013). The Acquisition of Teh and Mah by The L2 Learners of Sundanese. Litera Vol. 2, no. 2, pp. 381 390.

Lardiere, D. (1998). Case and Tense in the "fosilized" Study State. Second Language Research, 14, 1-26.

Leech, G. (2014). The Pragmatics of Politeness. New York: Oxford University Press.

Long, M. (2003). Stabilization and Fossilization in Interlanguage Development. Dalam Doughty, C., \& Long, M.H. The Handbook of Second Language Acquisition. Oxford, UK: Blackwell.

Moeljadi, D., et al. (2016). Kamus Besar Babasa Indonesia. Badan Pengembangan dan Pembinaan Bahasa, Kementrian Pendidikan dan Kebudayaan Republik Indonesia. Moleong, L. (2006). Metodologi Penelitian Kualitatif. (Edisi Revisi). Bandung: Remaja Rosdakarya.
Mueller, J., \& Jiang, N. (2013). The Acquisition of the Korean Honorific Affix (u) si by Advanced L2 Learners. The Modern Language Journal, 97, 2, pp. 318-339. DOI: $10.1111 / j .1540$ 4781.2013.12005.x.

Rasinger, S. M. (2010). Quantitative Methods: Concept, Framework and Issues. Dalam Litosseliti, L. (2010). Research Methodes in Linguistics. New York: Continuum International Publishing Group.

Shafa. (2015). Teori Pemerolehan Bahasa dan Implikasinya dalam Pembelajaran. STAIN Samarinda.

Song, J.J. (2006). The Korean Language. Structure, Use and Context. ( $2^{\text {nd }}$ Edition). London dan New York: Routledge. Sorace, A.(2005). Selective Optionality in Language Development. Dalam Cornips, L., \& Corrigan, K.P. (2005). Syntax and Variation: Reconciling and Biological and the Social, 55-80. Amsterdam: John Benjamins.

Tsimpli, I. M., \& Sorace, A. (2006). Differentiating Interfaces: L2 Peformance in Syntax Semantics and Syntax Discourse Phenomena. Dalam Bamman, D, Magnitskaia, T., \& Zaller, C. (Eds). Proceedings of the 30th annual Boston University Conference on Language Development, BUCLD 30, 653-664.

Somerville: Cascadilla Press.

Valenzuela, E. (2006). L2 end state Grammars and Incomplete Acquisition of Spanish CLLD Constructions. Dalam Slabakova, R, Montrul, S., \& Prevost, P. (eds). Inquiries in Linguistic Development: In Honor of Lidya White, 283-304. Amsterdam: John Benjamins.

Van Patten, B. (2002). Processing Instruction: An Update. Language Learning. 52, 755-803. 


\section{LAMPIRAN}

Lampiran 1. Instrumen Non-Tes Penelitian

Nama :

Usia :

Pertama kali belajar bahasa Korea sejak :

\section{Tata cara pengerjaan instrumen:}

1. Baca terlebih dahulu dan pahami konteks situasi dalam bahasa Indonesia yang tertera.

2. Setelah itu, baca dengan teliti kalimat bahasa Korea yang berada di bawah penjelasan konteks dan situasi.

3. Pilihlah B jika menganggap kalimat berbahasa Korea sesuai atau cocok dengan konteks situasi, dan pilihlah $\mathbf{S}$ jika menganggap kalimat berbahasa Korea tidak sesuai atau tidak cocok dengan konteks situasi. Tandailah $\mathbf{B}$ atau $\mathbf{S}$ dengan tanda silang.

\section{Kerjakan soal berikut!}

1. Seorang siswa memberitahu kepada salah satu gurunya bahwa kakak kelas pada masa SMA, sekarang sudah menjadi seorang dosen.

(B / S) 선생님, 제 선배는 교수에요

2. Seorang anak berusia 5 tahun, memberitahu ibunya bahwa kakak laki-lakinya baru saja datang dari Amerika

(B / S) 어머니, 형이 오셨어요.

3. Seorang anak memberitahu neneknya bahwa kakak perempuannya baru saja pulang kerja.

$(\mathrm{B} / \mathrm{S})$ 할머니, 누나가 지금 왔습니다.

4. Seorang ibu rumah tangga baru saja selesai menyiapkan makan malam, dan memberitahu anak bungsungnya untuk mengajak ayahnya makan malam bersama.

$(\mathrm{B} / \mathrm{S})$ 애야, 아버지 진지 잡수시라고해

5. Seorang guru yang baru bekerja 1 bulan menyuruh salah satu muridnya untuk memberitahu guru senior Lee agar datang rapat di lantai 2.

\section{$(\mathrm{B} / \mathrm{S})$ 학생, 이 선생님 빨리 2층에 오시라고 해}

6. Bibi saya baru saja menyuruh saya untuk memberitahu paman agar minum obat tepat waktu.

(B / S) 삼촌께 시간 맞춰 약을 먹어라고 해라

7. Seorang anak perempuan yang sudah bersuami, memberi kabar kepada ayahnya kalau suaminya baru saja berangkat kerja.

\section{$(\mathrm{B} / \mathrm{S})$ 아버지, 제 남편이 방금 출근했어요.}

8. Seorang anak perempuan yang sudah bersuami, memberi kabar kepada ayahnya kalau suaminya baru saja berangkat kerja.

$(\mathrm{B} / \mathrm{S})$ 아버지, 내 남편이 방금 가셔요.

9. Seorang ibu rumah tangga baru saja selesai menyiapkan makan malam, dan memberitahu anak bungsungnya untuk mengajak ayahnya makan malam bersama.

(B / S) 애야, 아버지 진지 먹어느냐 
10. Ibu saya bertanya kepada adik saya yang masih berumur 5 tahun, bertanya mengenai suaminya yang sudah berangkat untuk kerja atau belum.

(B / S) 영수야, 아버지 회사에 가셨니?

11. Seorang siswa memberitahu kepada salah satu gurunya bahwa kakak kelas pada masa SMA, sekarang sudah menjadi seorang dosen.

(B / S) 선생님, 제 선배가 교수가됐어요

12. Seorang anak berusia 5 tahun, memberitahu ibunya bahwa kakak laki-lakinya baru saja datang dari Amerika

$(\mathrm{B} / \mathrm{S})$ 어머니, 형이 돌아오셔요.

13. Bibi saya baru saja menyuruh saya untuk memberitahu paman agar minum obat tepat waktu.

$(\mathrm{B} / \mathrm{S})$ 삼촌께시간 맞춰 약을 드시라고 해라

14. Seorang guru yang baru bekerja 1 bulan menyuruh salah satu muridnya untuk memberitahu guru senior Lee agar datang rapat di lantai 2.

(B / S) 학생, 이 선생님 빨리 2층에 오지요

15. Ibu saya bertanya kepada adik saya yang masih berumur 5 tahun, bertanya mengenai suaminya yang sudah berangkat untuk kerja atau belum.

(B / S) 영수야, 너의 아버지 회사에 나가셨니?

16. Seorang anak berusia 5 tahun, memberitahu ibunya bahwa kakak laki-lakinya baru saja datang dari Amerika

$(\mathrm{B} / \mathrm{S})$ 어머니, 형이 돌왔어요.

17. Seorang anak memberitahu neneknya bahwa kakak perempuannya baru saja pulang kerja.

(B / S) 할머니, 누나가 지금 오십니다

18. Seorang siswa memberitahu kepada salah satu gurunya bahwa kakak kelas pada masa SMA, sekarang sudah menjadi seorang dosen.

(B / S) 선생님, 제 선배는 교수시에요

19. Seorang ibu rumah tangga baru saja selesai menyiapkan makan malam, dan memberitahu anak bungsungnya untuk mengajak ayahnya makan malam bersama.

(B / S) 애야, 아버지 진지 먹어해라

20. Seorang guru yang baru bekerja 1 bulan menyuruh salah satu muridnya untuk memberitahu guru senior Lee agar datang rapat di lantai 2.

(B / S) 학생, 이 선생님 빨리 2층에 와 
Mardhiyah, Syihabuddin, Kurniawan, \& Samsudin, Pemerolehan Honorifik Bahasa Korea ...

Lampiran 2. Persebaran Konteks Situasi yang terdapat dalam Soal Non-Tes

\begin{tabular}{|c|c|c|c|c|}
\hline No & Konteks Situasi & $\begin{array}{c}\text { Pernyataan Bahasa } \\
\text { Korea }\end{array}$ & Status & $\begin{array}{l}\text { Terdapat } \\
\text { pada No. }\end{array}$ \\
\hline
\end{tabular}

\section{Kondisi (1)}

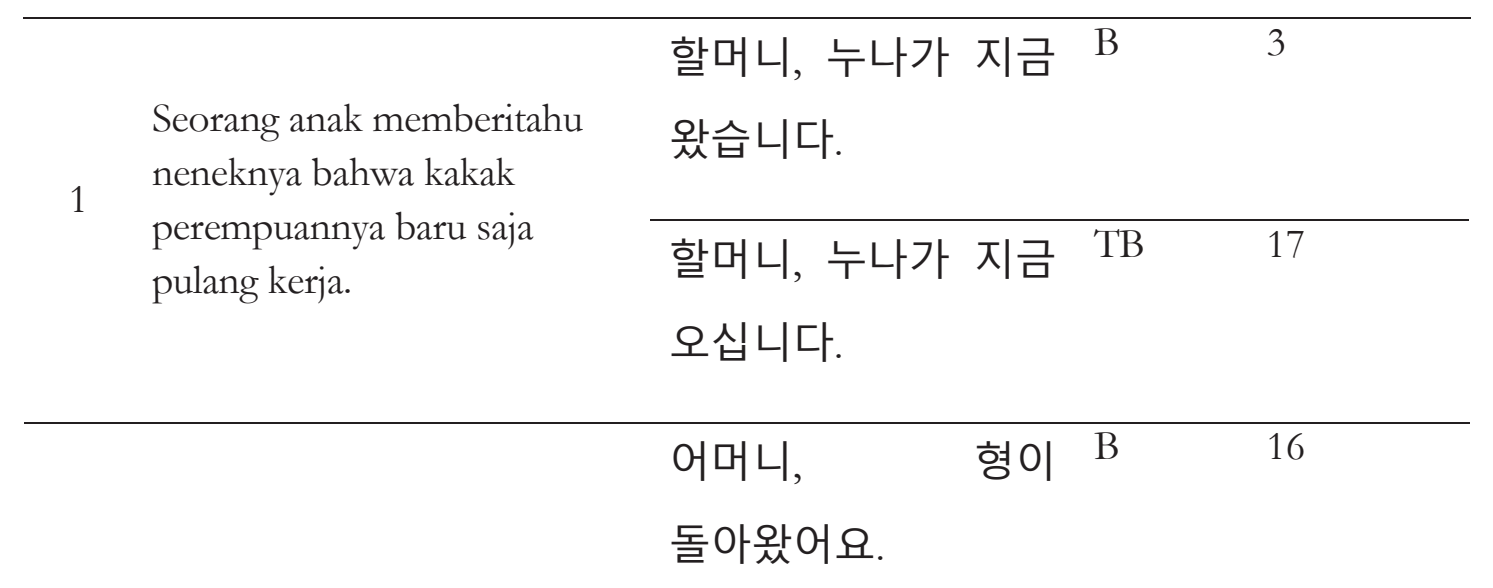

Seorang anak berusia 5 tahun, memberitahu ibunya bahwa kakak laki-lakinya baru saja datang dari Amerika.

어머니, 형이 $\quad$ TB 12

돌아오셔요.

\begin{tabular}{l}
\hline 어머니, 형이 TB \\
오셨어요. (Pengecoh)
\end{tabular}

Seorang anak perempuan

아버지, 제 남편이 $\mathrm{B} \quad 7$ yang sudah bersuami, 방금 출근했어요.

3 memberi kabar kepada ayahnya kalau suaminya baru saja berangkat kerja.

아버지, 내 남편이 $\mathrm{TB} \quad 8$
방금 가셔요.

선생님, 제 선배가 $\mathrm{B} \quad 11$ 교수가됐어요

Seorang siswa memberitahu kepada salah satu gurunya

4 bahwa kakak kelas pada masa SMA, sekarang sudah menjadi 선생님, 제 선배는 $\mathrm{TB} \quad 1$ 교수에요 (Pengecoh) seorang dosen.

선생님, 제 선배께는 $\mathrm{TB} \quad 18$
교수시에요


Jurnal Pendidikan Bahasa dan Sastra, Volume 18, Nomor 2, Oktober 2018, pp. 174- 192

\section{Kondisi (4)}

\begin{tabular}{|c|c|c|c|c|}
\hline \multirow{4}{*}{5} & \multirow{4}{*}{$\begin{array}{l}\text { Ibu saya bertanya kepada adik } \\
\text { saya yang masih berumur } 5 \\
\text { tahun, bertanya mengenai } \\
\text { suaminya yang sudah } \\
\text { berangkat untuk kerja atau } \\
\text { belum. }\end{array}$} & 영수야, 아버지 & $\mathrm{B}$ & 10 \\
\hline & & 회사에 가셨니? & & \\
\hline & & 영수야, 너의 아버지 & TB & 15 \\
\hline & & 회사에 나갔니? & & \\
\hline \multirow{6}{*}{6} & \multirow{6}{*}{$\begin{array}{l}\text { Seorang ibu rumah tangga } \\
\text { baru saja selesai menyiapkan } \\
\text { makan malam, dan } \\
\text { memberitahu anak } \\
\text { bungsungnya untuk mengajak } \\
\text { ayahnya makan malam } \\
\text { bersama. }\end{array}$} & 애야, 아버지 진지 & $\mathrm{B}$ & 4 \\
\hline & & 잡수시라고해. & & \\
\hline & & 애야, 아버지 진지 & TB & 19 \\
\hline & & 먹어해라 & & \\
\hline & & 애야, 아버지 진지 & TB & 9 \\
\hline & & 먹어느냐. (Pengecoh) & & \\
\hline \multirow{4}{*}{7} & \multirow{4}{*}{$\begin{array}{l}\text { Bibi saya baru saja menyuruh } \\
\text { saya untuk memberitahu } \\
\text { paman agar minum obat tepat } \\
\text { waktu. }\end{array}$} & 삼촌께 시간 맞춰 & $\mathrm{B}$ & 13 \\
\hline & & 약을 드시라고 해라 & & \\
\hline & & 삼천께 시간 맞춰 & TB & 6 \\
\hline & & 약을 먹어라고 해라 & & \\
\hline \multirow{8}{*}{8} & \multirow{8}{*}{$\begin{array}{l}\text { Seorang guru yang baru } \\
\text { bekerja } 1 \text { bulan menyuruh } \\
\text { salah satu muridnya untuk } \\
\text { memberitahu guru senior Lee } \\
\text { agar datang rapat di lantai } 2 \text {. }\end{array}$} & 학생, 이 선생님께 & $\mathrm{B}$ & 5 \\
\hline & & 빨리 2층에 오시라고 & & \\
\hline & & 해 & & \\
\hline & & 학생, 이 선생님 빨리 & TB & 20 \\
\hline & & 2층에 와 & & \\
\hline & & 학생, 이 선생님 빨리 & TB & 14 \\
\hline & & 오지요. & & \\
\hline & & (Pengecoh) & & \\
\hline
\end{tabular}

